\title{
Economic analysis of integrated farming systems in the Kuttanad region of Kerala state, India: A case study
}

\begin{abstract}
Aiswarya Sabu
Department of Agricultural Economics, Centre for Agricultural and Rural Development Studies (CARDS), Tamil Nadu Agricultural University, Coimbatore-641003 (Tamil Nadu), India
\end{abstract}

\section{S Padma Rani*}

Department of Agricultural Economics, Centre for Agricultural and Rural Development Studies (CARDS), Tamil Nadu Agricultural University, Coimbatore-641003 (Tamil Nadu), India

\section{A Vidhyavathi}

Department of Agricultural Economics, Centre for Agricultural and Rural Development Studies (CARDS), Tamil Nadu Agricultural University, Coimbatore-641003 (Tamil Nadu), India

*Corresponding author: Email: padmaranisentil@yahoo.com

\begin{abstract}
Agriculture, with its allied sectors, is unquestionably the largest livelihood provider in India. According to Committee on Doubling of Farmers' Income Report, the average annual earning of a small and marginal farmer household was Rs 79,779 in 2015-16 and indicates that $86 \%$ of farmer households earn only $9 \%$ of total income and rest of the farmers earn $91 \%$ of total income. Integrated farming system practised mostly by small and marginal farmers, is a viable option for increasing farm income. The present study was undertaken to identify the farming systems practised by small and marginal holdings in Kuttanad region of Kerala state, India and also attempts to assess the profitability of these farms and suggest optimal farm plans using linear programming technique. The study revealed that rice + fish and Coconut + Banana+ Dairy cow + Poultry+ Goat were the most profitable farming systems with a benefit cost ratio of 2.63 and 2.86 , respectively. The resource allocation in the existing plan was sub-optimal. The optimisation of resource use led to maximization of net returns, indicating the potential for realising greater income. The net returns of rice + fish increased from Rs. 181724 to Rs. 220010 in the optimal plan. The study also suggests the extent to which net returns can be increased with additional units of constraint resources viz., land/labour. The net returns in FS IV can be increased by Rs.286177.9 per additional acreage of land allotted. Thus, the farmers in Kuttanad can increase their income by optimal resource allocation and by deploying additional units of land or labour.
\end{abstract}

Keywords: Integrated farming system, Linear programming, Optimisation, Shadow price

\section{Article Info}

https://doi.org/10.31018/

jans.vi.2292

Received: May 10, 2020

Revised: June 11, 2020

Accepted: June 13, 2020

\section{How to Cite}

Sabu, A. et al. (2020) Economic analysis of integrated farming systems in the Kuttanad region of Kerala state, India: A case study. Journal of Applied and Natural Science, 12 (2): 270 - 276 https://doi.org/10.31018/ jans.vi.2292

\section{INTRODUCTION}

In India, agriculture is the largest enterprise and it can only survive if it can grow consistently. The growth of agriculture as an enterprise is dependent upon investment and savings, which are a function of net returns. The net returns in this enterprise in turn determine the level of income of the farmer as per report of the Committee on Doubling of Farmers Income (Government of India, 2017). An increase in farmer's income will help to decrease the agrarian distress in India. Indian agriculture is dominated by small and marginal holders, and this does not allow the adoption of technology by farmers and efficient utilisation of farm resources. According to Agricultural Census 2015 -16, India has an estimated 12.56 crore small and marginal farmers. They together operate 86 per cent of the total farm holdings and held 47.34 per cent in the operated area.

In comparison, the large and medium farmers operate under 30 per cent of the farm area. Kerala has an estimated 75 lakh small and medium farmers, who together operate 99 per cent of the total farm holdings and held 78.70 per cent in the operated area. According to Committee on Doubling of Farmer's Income Report, the average annual earning of a small and marginal farmer household was Rs. 79779 in 2015-16 and this indicates that 86 per cent of farmer households 
earn only 9 per cent of total income and the rest earn income 91 per cent of total income. Thus, it is imperative to increase the income of small and marginal farmers through sustainable means for the upliftment of the economy as a whole.

As per the Agricultural Census 2015-16, the average landholding size is 0.18 ha, and it was 0.22 ha in 2010-11. This necessitates a system that integrates various farming components while assuring a reasonable return to the farm family (Nataraja, 2016). An integrated farming system with available resources accessible to farmers ensures a high standard of food production with minimum environmental impact even in highly vulnerable climate. It is a viable option for small and marginal farmers. It has revolutionised the conventional farming of livestock, aquaculture, poultry, horticulture, agroforestry and allied sector (Mamatha, 2017).

Integrated Farming System (IFS) is a dynamic concept and a practical way forward for agriculture that benefits not only the farmers but also the society as a whole. A major advantage of the IFS approach is that it generates additional income and employment to the tune of 200 to 400 per cent and thereby increasing the standard of living of farm families. Padmanabhan et al. (2001) studied the economic viability of integrated farming system model in Kumarakom, Kerala and concluded that the rice+ fish+ pig+ cow+ poultry model yielded a net income of Rs. 1, 29,508 from the integrated farming model. Dadhwal et al. (2012) suggested integrated farming systems suited for Western Himalayas and concluded that such systems improve productivity, provide employment opportunities for small and marginal farmers and increase resource use efficiency in farms. The study also found that farming systems based on small scale poultry unit recovered with an overall $\mathrm{BC}$ ratio of 1.9:1.

Felix et al. (2013) used linear programming model for small farmers in Bindura district, Zimbabwe and found that the LP model with optimal resource allocation yielded a gross income of $\$ 12,295.10$ as compared to $\$ 8,500.00$ obtained in traditional resource use methods. According to the Report of Committee on DFI ( Vol I), the risk in agriculture can be reduced to a great extent by practising IFS so that the farmers get an assured income from any of the enterprise during adverse conditions.

The Regional Agricultural Research Station (RARS), Problem Zone under Kerala Agricultural University and the Committee on Doubling of Farmers Income under Government of Kerala recommends integrated farming system models for farmers in Kuttanad. The Kerala State Planning Board in its report titled "A Special Package for Post Flood Kuttanad", 2019 recommended "Integrated farming in paddy fields with multicommodity enterprises" and "revival of coconut farming" through crop and livestock enterprises. The present study was undertaken to identify the major integrated farming systems of Kuttanad, Kerala. The study also attempts to assess the economics of integrated farming system and suggest optimum farm plans for small and marginal farm holdings.

\section{MATERIALS AND METHODS}

Study area: A primary survey was conducted in Kuttanad, popularly known as the rice bowl of Kerala. About $95 \%$ of farmers in Kuttanad are small and marginal farmers. Kuttanad spans across Alappuzha, Kottayam and Pathanamthitta districts of Kerala. About 32 panchayats of Alappuzha district, 32 panchayats of Kottayam district and five districts of Pathanamthitta district constituted Kuttanad region or Kuttanad Wetland System (KWS). One panchayat from each of the three districts was chosen for the study. Niranam panchayat of Alappuzha district, Kumarakom panchayat of Kottayam district and Nedumudi district of Pathanamthitta district were selected. A map demarcating Kuttanad or KWS is shown in Fig. 1. Random sampling was undertaken to select forty farmers from each panchayat. The total sample size of 120 included both small and marginal farmers.

Method of data collection: Primary data was collected from the sample respondents by personal interview method with the help of pre-tested interview schedule, specifically designed for the study. General information like age, educational status, family details, landholding pattern, cropping pattern, and inventory of farm assets and details of livestock inventory were collected from respondents. Detailed information on the integrated farming system model, cost and returns of crop, cost and returns of livestock enterprises, cost and returns of the fishery were also collected from the respondents. The primary data were collected from the respondents with the help of a personal interview conducted during December 2019 and January 2020. The primary data collected from the sample respondents were processed and tabulated.

Method of data analysis: In order to analyse the cost of cultivation, all operational cost, material cost and fixed cost were taken into account. For livestock enterprises, fixed cost involves depreciation on poultry shed and interest on fixed capital assets (Osti, 2016). Fixed cost for fishery component involved depreciation on pond and interest on fixed capital assets. Variable cost included cost incurred in purchase, cost of feed, labour cost, medicine cost and interest on variable cost for livestock enterprises (Osti, 2016).

Linear programming was used to suggest optimum farm plans using the given resources. Linear programming is a mathematical modelling tech- 
nique used to determine the level of operational activity in order to achieve an objective, subject to restrictions called constraints. The optimum allocation was the one which showed the activities to undertake under physical and technical resource conditions and the amount of resource to be allocated to each activity so that the net returns in a year are maximized (Nataraja, 2016). Linear programming, one of the most appropriate tools, was used to allocate limited farm resources. The mathematical formulation of the linear programming model (Nataraja, 2016) is given below:

Maximize $Z=\Sigma c_{k} y_{k}+\Sigma a_{j} x_{j}$ Subject to

Where

$$
\Sigma b_{i k} y_{k}+\Sigma b_{i j} x_{j} \leq G_{i}
$$

$Z$ - Total net returns to maximize

$\mathrm{c}_{k}$ - Net returns of the $k^{\text {th }}$ crop enterprise

$y_{k}$ - Amount of the $k^{\text {th }}$ crop enterprise

$a_{j}-$ Net returns from the $j^{\text {th }}$ poultry enterprise

$x_{j}$ - Amount (poultry unit) of the $j^{\text {th }}$ poultry enterprise

$b_{i j}$ - ith resource of the $j^{\text {th }}$ poultry enterprise

$b_{i k}$ - ith resource of the $k^{\text {th }}$ crop enterprise

$\mathrm{G}_{\mathrm{i}}$ - Maximum level of $\mathrm{i}^{\text {th }}$ resource available

The gross returns of the crop enterprises and other allied enterprises per acre were calculated using data collected from the primary survey. The net returns were arrived by subtracting the expenses of the farmer producer. The net returns of livestock components were calculated by subtracting expenses on feed, labour, medicine etc. The basic assumptions of the model include linearity, additivity, certainty, proportionality and divisibility. The problems of resource allocation in the study were based on the assumption that the economic decision-making unit is the farm, and the farmer has the sole right to make decisions regarding resource allocation and farm management.

Another major assumption of the model was its operational period. The operational period of the model was twelve months. The yield and price expectations of the farmers were assumed to be single-valued in the model. The model also assumed that each farm was operated such a way so as to maximize the net returns subject to resource constraints.

The activities in the model indicated the resources often put into alternative uses. The model had the following activities: i). Crop, poultry, dairy and fishery activities, ii). Labour hiring activities, iii). Perennial crop cultivation, iv). Sale of product activities, v). Working Capital.

The constraints included in the LP model were land, labour, working capital, fertilizer and feed. The land, labour and working capital available, chemical fertilizers and farm yard manure availa-

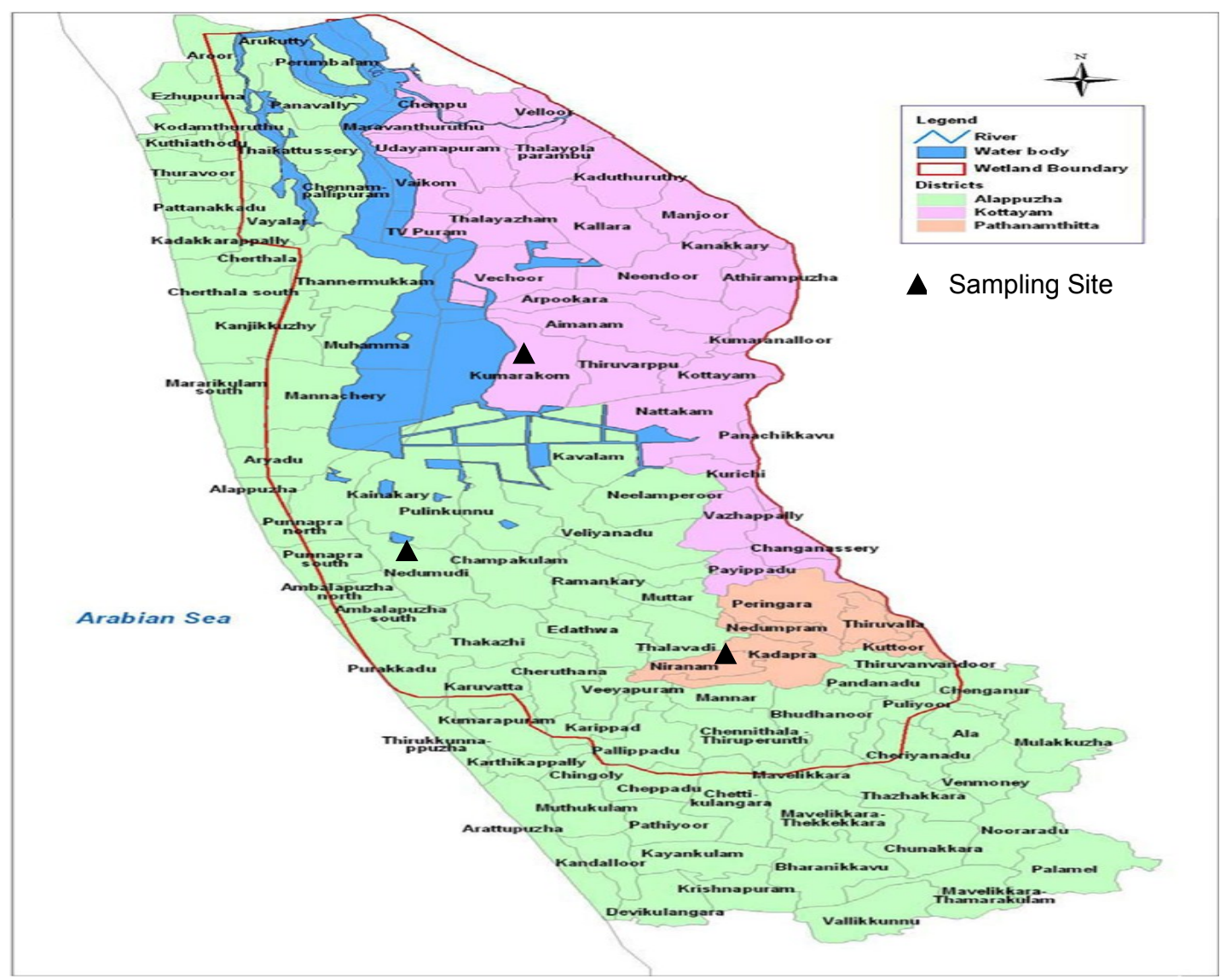

Fig. 1. Delimitation map of Alappuzha district and Kuttanad Region of Kerala state (Source: MSSRF Report , 2007). 
ble for cultivation, feed available for livestock and other allied enterprises like fishery were considered. In the case of labour available, both family labour and hired labours were considered. In this study, input coefficients were land, labour, fertilizer requirement, farmyard manure and feed requirements. The feed requirements for poultry, dairy and fishery were considered. In the case of land, owned land was considered. Labour includes both family and hired labour. The inputoutput coefficients for an average farm were derived from primary data collected. The linear programming problem was solved with Microsoft Excel using the solver option.

\section{RESULTS AND DISCUSSION}

The small and marginal farmers in Kuttanad emphasised on both crop and livestock activities. About 71 per cent of farmers in the study area possessed livestock components like dairy, small ruminants and poultry and about $29 \%$ of the farmers were engaged in the fishery. The major crop activities were rice, coconut and banana. Rice was the major crop cultivated in the study area. The average size of land holdings of marginal and small farm households are given in table 1. More than half of the sample farmers (54 per cent) were marginal farmers. The average size of marginal farm holding was 1.20 acres, whereas it was 3.69 acres in case of small farm holdings.

Farming systems: The integrated farming systems identified in the study area are presented in table 2. Rice-based and coconut-based systems were the major farming systems in the study area. Rice + Fishery (FS II) formed the most common integrated farming system followed by the sample farmers in Kuttanad, accounting for 31 per cent of the total. Among 55 small farmers, the most common system was Rice + Fishery (45.5 per cent) followed by Rice + Duckery (23.6 per cent). Rice + Duckery system (FS I) was followed by 34 per cent of marginal farmers and 26 per cent follow Coconut + Banana + Poultry system (FS III). Among the coconut-based farming system, Coconut + Banana + Poultry was the most common system. Coconut + Banana + dairy cow system (FS IV) was practised by 6 per cent of the sample farmers whereas Coconut + Banana + Poultry + dairy Cow system (FS VII) was followed by 4.1 per cent of the respondents. Other coconut-based systems namely Coconut + Poultry + dairy cow (FS V) and Coconut + Banana + Poultry + Goat (FS VIII) were practised by only a small proportion of the farmers' viz., 2.5 per cent and 1.6 per cent respectively. Coconut + Banana + Goat system (FS V) was followed only in a small farm household. Similarly, Coconut + Banana + Poultry + Goat + dairy cow system (FS VII) were followed by a single marginal farm household. The ricebased farming system was identified as the major

farming system in Kuttanad, and the allied enterprises included fishery, duckery, dairy and poultry and these results are same as in the study conducted in Kuttanad region, Kerala by Mamatha (2017).

Net income: The annual net income of the farming systems in the study area is shown in Table 3. Among the rice-based systems, rice + fishery (FS II) was the most profitable system with a net income of Rs. 181725.58 and benefit-cost ratio of 2.63. The results are in agreement with recommendations of "A Special Package for Post-Flood Kuttanad" Report (2018), integration of fisheries with agriculture is the best way to increase the profitability of farming households in Kuttanad. Crop + Dairy cow + Poultry+ Goat (FS VII) was the most profitable system among the coconutbased farming systems in the study area. Being the most diversified system, the annual net income of FS VII is Rs. 1964503.57 with a benefitcost ratio of 2.86. This result indicated that as the degree of integration increases, net returns of the system also increases. A similar result was observed in the study conducted by Nataraja (2016) in Chikkaballapura district, Karnataka. Coconut + Poultry + Cow (FS V) and Coconut + Banana + Goat (FS VI) systems appeared to be the least profitable systems relatively with a benefit-cost ratio of 1.24 and 1.51 respectively. The total cost and net income of FS V appeared to be Rs. 744352.93, and Rs. 183594.57 respectively.

Optimal plans: The enterprise combinations of the existing, as well as optimal farm plans of the farming systems identified in Kuttanad, are presented in Table 4 to 5 . The major objective of optimisation was to increase the net income, and this has been achieved in all farming systems. The increase in net returns was highest in case of FS VII from Rs 192223 to Rs 462367 . The results of the LP model indicated that major crop activities identified like rice and coconut appeared in the optimum plans as they were found to be remunerative. The crop activity banana being less remunerative did not appear in optimum farm plans of FS III, FS VII and FS IX. All the livestock activities under the existing farm plan appeared in the optimum plans.

Since land, human labour and working capital were constraints, the amount of these resources available were fully utilised in most farming systems. The land was fully utilised in FS IV, FS V,

Table 1. Average size of the landholdings in different categories of farm households of Kuttanad.

\begin{tabular}{ccc}
\hline Types of farmers & $\begin{array}{l}\text { Number of } \\
\text { farmers }\end{array}$ & $\begin{array}{l}\text { Average land- } \\
\text { holding size } \\
\text { (acres) }\end{array}$ \\
\hline Marginal farmers & 65 & 1.20 \\
Small farmers & 55 & 3.69 \\
\hline
\end{tabular}


Sabu, A. et al. / J. Appl. \& Nat. Sci. 12(2): 270 - 276 (2020)

Table 2. Integrated farming system followed by sample farmers of Kuttanad.

\begin{tabular}{lllll}
\hline $\begin{array}{l}\text { Farming } \\
\text { system }\end{array}$ & Farming System & $\begin{array}{l}\text { No. of marginal } \\
\text { Farmers }\end{array}$ & $\begin{array}{l}\text { No. of small } \\
\text { farmers }\end{array}$ & Total \\
\hline FS I & Rice + Duckery & $22(34)$ & $13(23.6)$ & $35(29)$ \\
FS II & Rice + Fishery & $12(18.4)$ & $25(45.5)$ & $37(31)$ \\
FS III & Coconut + Banana + Poultry & $17(26.1)$ & $11(20)$ & $28(24)$ \\
FS IV & Coconut + Banana + Cow & $7(10.76)$ & $1(1.8)$ & $8(6)$ \\
FS V & Coconut + Poultry + Cow & $2(3.07)$ & $1(1.8)$ & $3(2.5)$ \\
FS VI & Coconut + Banana + Goat & 0 & $1(1.8)$ & $1(0.83)$ \\
FS VII & Coconut + Banana + Poultry + Cow & $3(4.6)$ & $2(3.6)$ & $5(4.17)$ \\
FS VIII & Coconut + Banana + Poultry + Goat & $1(1.53)$ & $1(1.8)$ & $2(1.6)$ \\
FS IX & Coconut + Banana + Poultry + Goat + Cow & $1(1.53)$ & 0 & $1(0.83)$ \\
& Total & $65(100)$ & $55(100)$ & $120(100)$ \\
\hline
\end{tabular}

Note: Figures in parenthesis indicate percentage to the total

Table 3. Annual net income (Rupees/annum) from existing integrated farming systems of Kuttanad.

\begin{tabular}{llllll}
\hline $\begin{array}{l}\text { Farming } \\
\text { system }\end{array}$ & Farming System & Total Cost & Gross Returns & Net Returns & BC Ratio \\
\hline FS I & Rice + Duckery* & 1010188.88 & 1549052.14 & 538863.26 & 1.53 \\
FS II & Rice + Fishery & 111355.81 & 293081.37 & 181725.58 & 2.63 \\
FS III & $\begin{array}{l}\text { Coconut+ Banana + Poul- } \\
\text { try** }\end{array}$ & 503334.66 & 1147197.9 & 643862.63 & 2.27 \\
& Coconut+ Banana + Cow & & & 2.17 \\
FS IV & 134284.6 & 292508.6 & 158223.9 & 1.24 \\
FS V & Coconut + Poultry + Cow & 744352.93 & 927947.67 & 183594.57 & 1.51 \\
FS VI & Coconut+ Banana + Goat & 163809.14 & 248325 & 184515.9 & 2.30 \\
FS VII & Coconut+ Banana + Poultry & 639200.91 & 1473329.1 & 834128.19 & 2.10 \\
& + Cow & & & & 214497.3 \\
FS VIII & Coconut+ Banana + Poultry & 645593 & 1361198 & & 2.86 \\
& + Goat & & & 1964503.57 & \\
FS IX & Coconut+ Banana + Poultry & 892821.76 & 2557325.33 & & 2.06 \\
& + Goat + Cow & & & 600435 & 0.54 \\
\hline
\end{tabular}

*Duckery- pre 1000 layers; ${ }^{* *}$ Poultry- per 1000 layers; ${ }^{* * *}$ Dairy- per cattle

Table 4. Existing vs Optimal plan for rice-based integrated farming systems of Kuttanad.

\begin{tabular}{llcccc}
\hline Particulars & Unit & \multicolumn{2}{c}{ FS I } & \multicolumn{2}{c}{ FS II } \\
\hline & & P 01 & P 11 & P 02 & P 12 \\
Rice & Acres & 3.09 & 1.28 & 2.34 & 1.26 \\
Fishery & Acres & 3.09 & 1.20 & & 85 \\
Duckery & Nos & & & 67 & 82 \\
Human Labour & MD & 160 & 145 & 120 & 58694.3 \\
Working Capital & Rs. & 185610.7 & 166866.5 & 58694.3 & 67017 \\
Net Returns & Rs. & 181724 & 220010 & 52814 & \\
\hline
\end{tabular}

P 01 - P 02 shows Existing plans; P 11 - P 12 shows optimal plans; ${ }^{*}$ Duckery unit shows no. of birds 
FS VI, FS VII and FS VIII. Human labour was fully utilised in FS III, FS IV, FS VI, FS VII and FS IX. Working capital was fully utilised in FS II and FS VIII. The shadow prices of fully utilised resources are presented in table 6 . The shadow price of land in FS IV is Rs.286177.9; this indicates that the net income in Kuttanad could be increased by Rs. 286177.9 per additional acreage of farmland allotted for FS IV. The shadow price of labour in FS III is Rs.285.3; this indicates that the net farm income in Kuttanad could be increased by Rs. 285.3 per additional man-days of labour allotted for FS III. The existing use of resources in Kuttanad was less than the optimum level, and these suggest that optimum farming system models help in increasing the net income of the farm families. The study conducted by Igwe and Onyenweaku (2013) in Aba agricultural zone of Nigeria and Nataraja (2016) in Chikkaballapura district, Karnataka also found that existing resource used by farmers was sub-optimal.

About 15 man-days of labour in FS I, 38 man-days in FS II, 26 man-days in FS V and 69 man-days of labour in FS VIII were left unused. Similarly, Rs. 6831 of working capital in FS III, Rs. 2825 in FS V, Rs. 408 in FS VI, Rs. 8577 in FS VII and Rs. 6848 of capital in FS IX were left unused. These results are in agreement with the findings of a study conducted in Central Niger Delta of Nigeria by Allison (2009), suggesting that the other complimentary resources available on the farm are not enough to be combined with these unused resources in order to achieve the objective of maximisation of net returns. Therefore, it is necessary to increase the area under cultivation and deploy more labour in order to utilise these unused resources.

\section{Conclusion}

Integrated farming systems are viable option to address the distress faced by small and marginal farmers. The study revealed that Coconut + Banana + Dairy cow + Poultry+ Goat and Rice + fish were the most profitable farming systems in the study area, with a benefit-cost ratio of 2.86 and 2.63 respectively. The allied activities practised by the farmers like fishery, duckery, poultry and dairy enterprises appeared to complement the crop activities in the study area. The farm resources in the existing plan were not optimally allocated. The optimisation of farm plans led to an increase in net returns and effective utilisation of available resources. The net returns can be increased with additional units of land/labour, as land and labour were the common resource constraint in all farming systems. Farmers in Kuttanad can attempt to increase the area under cultivation and deploy more labour in order to utilise the excess resources and to realise higher income. 
Sabu, A. et al. / J. Appl. \& Nat. Sci. 12(2): 270 - 276 (2020)

Table 6. Shadow prices (Rupees) of fully utilized resources of Kuttanad.

\begin{tabular}{|c|c|c|c|c|c|c|c|c|c|}
\hline Resources & FS I & FS II & FSIII & FS IV & FS V & FS VI & FS VII & FS VIII & FS IX \\
\hline Land & $-^{*}$ & - & - & 11953.2 & 4059.9 & 24895.09 & 286177.9 & 6749.33 & - \\
\hline Labour & - & - & 285.3 & 44.78 & - & 310.74 & 33.17 & - & 761.05 \\
\hline $\begin{array}{l}\text { Working } \\
\text { capital }\end{array}$ & 1.10 & - & - & - & - & - & - & 0.73 & - \\
\hline FYM & - & - & - & - & - & - & - & - & - \\
\hline $\mathrm{N}$ & - & 308.98 & - & - & - & - & - & - & 2635.96 \\
\hline$P$ & 18.45 & - & - & - & - & - & - & - & - \\
\hline K & - & - & 56.35 & - & - & - & - & 1109.82 & - \\
\hline Fish feed & - & 105.06 & - & 9.91 & 234.00 & 2.88 & 122.82 & - & - \\
\hline
\end{tabular}

*- sign indicates unused resources

\section{REFERENCES}

1. Dadhwal, $\mathrm{K}$ and Tomar, Jagmohan and Muthiah, Muruganandam and Kaushal, R. and Chaturvedi, Om Prakash. (2012). Integrated Farming Systems for Food and Nutritional Security in North Western Himalayas. Indian Forester, 138: 689-696 10.36808/if/20 12/v138i8/14129.

2. Felix, M., Judith, M., Jonathan, M., and Munashe, S. (2013). Modelling a Small Farm Livelihood System using Linear Programming in Bindura, Zimbabwe. Research. J. Manag. Sci., 2 (5): 20-23. 10.5897/AJAR10.0 28.

3. Government of India (2019). "Agricultural Census 2015-16 (Phase-I)- All India Report on Number and Area of Operational Holdings": Department of Agriculture, Cooperation and Farmers Welfare, Ministry of Agriculture and Farmers' Welfare, New Delhi.p 97.

4. Government of India (2017). "Report of the Committee on Doubling of Farmers Income: Vol 1", Ministry of Agriculture and Farmers' Welfare, Govt. of India, New Delhi.

5. Government of Kerala (2019). "A Special Package For Post-Flood Kuttanad", Kerala State Planning Board, Govt. of Kerala, Thiruvananthapuram.

6. Igwe, K. C. and Onyenweaku, C. E. (2013). A linear programming approach to food crops and livestock enterprises planning in Aba Agricultural Zone of Abia State, Nigeria. Am. J. Exp. Agric., 3(2): 412-431.

7. Mamatha, G. Nair. (2017). Multidimensional Analysis of Farmers of Integrated Farming system in Kuttanad.
M.Sc. Thesis. Department of Agricultural Extension. Kerala Agricultural University. Thrissur.

8. MSSRF (2007). Measures to Mitigate Agrarian Distress in Alappuzha and Kuttanad Wetland Ecosystem, A Study Report, M. S. Swaminathan Research Foundation, Chennai.

9. Nataraja, H. M. (2016). An Economic Analysis of Integrated Farming System in Sidlaghatta Taluk of Chikkaballapura District, Karnataka. M.Sc. Thesis. Department of Agricultural Economics. University of Agricultural Sciences. Bengaluru.

10.Oguru, Allison., Igben, M. S. and Chukwuigwe E. C. (2009). "Revenue maximising combination of rice monocrop and cassava-based farm enterprises in the Central Niger Delta: A linear programming solution". Ghana Jnl. Agric. Sci., 42: 123-130. 10.4314/ gjas.v42i1-2.60651

11.Osti, Rajani and zhou, Deyi and Singh, Virendra and Bhattarai, Dinesh and Choudhary, Harshika. (2016). An economic analysis of poultry egg production in Nepal. Pakistan Journal of Nutrition, 15: 715-724. 10.3923/pjn.2016.715.724.

12.Padmanabhan, P G., Narayanan, N. C. and Padmakumar, K. G. (2001) Integrated Farming Systems, In Economic Viability of an Integrated and Sustainable Resource Use Model for Kuttanad. Kerala Research Programme on Local Level Development, Centre for Development Studies, Centre for Development Studies, Thiruvananthapuram pp 19-36. 